\title{
The substantiation of adoptive transfer of tolerogenic dendritic cells for treatment of rheumatoid arthritis in mice
}

\author{
Goltsev A. M., Dubrava T. G., Yampolska K. Ye., Lutsenko O. D., Gaevska Yu. O., Babenko N. M., Bondarovych M. O. \\ Institute for Problems of Cryobiology and Cryomedicine of the National Academy of Sciences of Ukraine, Kharkiv, Ukraine \\ e-mail: yampi@ukr.net
}

\section{ABSTRACT}

The tolerogenic properties of dendritic cells are of particular interest in the search for new approaches to the correction of Treg immunity in the treatment of autoimmune diseases.

The PURPOSE is to study the effect of tolerogenic dendritic cells on the Treg immunity in mice with adjuvant arthritis at different stages.

MATERIALS AND METHODS. Adjuvant arthritis (AA) was induced in CBA/H mice by sub-plantar injection of the Freund's complete adjuvant. Dendritic cells were obtained ex vivo from bone marrow mononuclear cells. On the $7^{\text {th }}, 14^{\text {th }}$ or $21^{\text {st }}$ days of adjuvant arthritis, animals were injected with tolerogenic dendritic cells. Their arthritis index and T-immune status (CD4+CD25+ and FOXP3 ${ }^{+}$cells) were assessed.

RESULTS. Dysfunction of Treg immunity and clinical diagnostic parameters in animals at different stages of adjuvant arthritis have been demonstrated. On the $14^{\text {th }}$ and $21^{\text {st }}$ days of adjuvant arthritis, immunotherapy by obtained ex vivo dendritic cells, contributed to the increase of $\mathrm{CD} 4^{+} \mathrm{CD} 25^{+}$and $\mathrm{FOXP}^{+}$cells content in the spleen and normalization of clinical diagnostic parameters in animals. In the acute stage of arthritis (7 days), adoptive therapy with tolerogenic dendritic cells was not effective.

CONCLUSION. Adoptive application of tolerogenic dendritic cells has contributed to the reduction of clinical manifestation of the arthritis. The greatest therapeutic efficacy was demonstrated by dendritic cells transferred on the $14^{\text {th }}$ day of the pathology development, which contributed to the normalization of the clinical status of recipients with adjuvant arthritis.

KEY WORDS: adjuvant arthritis; adoptive immunotherapy; tolerogenic dendritic cells; Treg cells

An important component of the rheumatoid arthritis (RA) pathogenesis is dysregulation of the immune system, which induces impaired tolerance to auto-antigens and the development of autoimmune reactions. An important role in the inhibition of the autoimmune response belongs to regulatory T-cells (Treg), whose level of suppressor activity is largely determined by the expression of the transcription factor gene forkhead box protein 3 (Foxp3), required for the normal functioning and development of Treg [1]. Foxp3 acts as a transcriptional repressor of proinflammatory cytokines, being an antagonist of NFAT (nuclear factor of activated T-cells) function, which is central in the formation of the immune response in inflammation [2]. There is a decrease in the number of suppressor cells and Foxp3 gene expression in patients with RA [3, 4]. One of the mechanisms of this process might be a violation of the pro- and anti-inflammatory cytokines balance. For example, the level of anti-inflammatory cytokines TNFa, IL-6, IL-1 $\beta$, IL-17 increases and IL-10, IL-4 decreases in the blood plasma at RA $[5,6]$. Therefore, the decrease in the level of proinflammatory cytokines may contribute to the restoration of Treg suppressor function.

To date, the most common method of RA treatment is immunosuppressive therapy, which can significantly reduce the degree of the disease symptoms, but has severe side effects, in particular, a general reduction of infection resistance, suppression of antitumor immunity, mutagenic and cytotoxic effect on cells. Important factors limiting the immunosuppressive therapy of RA include the resistance to previously effective drugs, which often occurs at their long-term use $[7,8]$. Thus, there is a need to find alternative treatments for RA. One of the promising therapeutic approaches is the application of autologous tolerogenic dendritic cells (tolDCs) [9, 10, 11, 12]. Dendritic cells represent a unique population of antigen-presenting cells that are capable of both stimulating and inhibiting the immune response. Tolerogenic DCs, unlike immunogenic 
cells, are characterized by low expression of co-stimulatory molecules, high expression of immune regulatory cytokines and the ability to induce T-cell anergy and apoptosis $[11,12]$. A new approach to the RA treatment is primarily aimed at the formation of tolerance to arthritic auto-antigens. However, the impact of tolDCs on natural antigen-specific Treg cells, which play a key role in tolerance to auto-antigens through inhibition of auto-reactive T-cells, remains unresolved. There are also no data on the efficacy of tolDCs therapy, depending on the time of cell transfer during the pathology development.

The PURPOSE of our study was to investigate the effect of tolDCs on the Treg immunity in mice with adjuvant arthritis (AA) at different stages of its development.

\section{MATERIALS AND METHODS}

The experiments were performed on female $\mathrm{CBA} / \mathrm{H}$ mice, 2.5-3 months old. The studies were conducted in accordance with the «General Principles of Animal Experiments", approved by the V National Congress on Bioethics (Kyiv, 2013) and agreed with the «European Convention for the Protection of Vertebrate Animals used for Experimental and Other Scientific Purposes» (Strasbourg, 1986). The animals were euthanized under ether anaesthesia by cervical dislocation.

Isolation of murine bone marrow cells. The bone marrow was flushed out from the femur of mice $(n=10)$ with complete RPMI-1640 medium (Sigma-Aldrich, UK) supplemented with $3 \%$ fetal calf serum (BioLot, Russia) and $2 \%$ sodium citrate (Sigma-Aldrich, USA). The suspension of bone marrow cells was passed through a nylon filter with a pore diameter of $100 \mu \mathrm{m}$ (Falkon, USA), centrifuged at $300 \mathrm{xg}$ for $10 \mathrm{~min}$ and resuspended in the complete medium.

Isolation of bone marrow mononuclear cells. Mononuclear cells (MNCs) were isolated by centrifugation of bone marrow suspension in density gradient Trazograph $1.077 \mathrm{~g} / \mathrm{cm}^{3}$ (Unic Pharmaceutical Laboratories, India) [12].

Obtaining of tolerogenic DCs. MNCs were cultured in $35 \mathrm{~mm}$ plastic Petri dishes in RPMI-1640 medium supplemented with $10 \%$ fetal calf serum and $1 \%$ antibiotic solution $(100 \mathrm{U} / \mathrm{ml}$ penicillin, $0.1 \mathrm{mg} / \mathrm{ml}$ streptomycin), at a concentration of $3-5 \cdot 10^{6}$ cells $/ \mathrm{ml}$ or $9 \cdot 10^{6}$ cells per dish. The cells were cultured at $37{ }^{\circ} \mathrm{C}$ in $5 \% \mathrm{CO}_{2}$ atmosphere. On 0 day, $20 \mathrm{ng} / \mathrm{ml}$ murine recombinant granulocyte-macrophage colony-stimulating factor GM-CSF (Sigma-Aldrich, UK), $5 \mathrm{ng} / \mathrm{ml} \mathrm{IL-4} \mathrm{(Sigma-Aldrich,} \mathrm{UK)} \mathrm{[13]} \mathrm{and}$ $0.4 \mu \mathrm{g} / \mathrm{ml}$ dexamethasone - Dex (Sigma-Aldrich, UK) [14] were added to the culture medium. After 3 days, a fresh culture medium with the factors and Dex was added. On the 6-7 $7^{\text {th }}$ days, non-adherent and weakly adherent cells were collected for further FACS analysis and injection to animals with adjuvant arthritis (AA). On 6-7 $7^{\text {th }}$ days of culture the relative content of tolDCs was $90 \%$ of the seeded cells or $8 \cdot 10^{6}$ cells/dish.

Induction of adjuvant arthritis. Adjuvant arthritis (AA) was induced in $\mathrm{CBA} / \mathrm{H}$ mice $(\mathrm{n}=15)$ by subplantar injection with $0.2 \mathrm{ml} /$ mouse Freund's Complete Adjuvant (Santa Cruz, USA). The development of AA was assessed using the arthritis index (Al), which is the ratio of the circumference of the test joint to the circumference of the control one. In healthy animals $(n=5)$ treated with saline at the same dose as Freund's Complete Adjuvant, IA was taken as 1 unit. The administration of saline did not cause a local inflammation.

Determination of inflammatory mediators at AA. The level of seromucoids in the serum of animals with AA was determined by the turbidimetric method using a kit of reagents (Felicit-Diagnostics, Ukraine) according to the manufacturer's instructions and was evaluated in turbidity units (S-H) by Shank and Hoagland. The level of sialic acids was determined by the Hess method [15].

Transfer of tolDCs to animals with AA. Syngeneic ex vivo grown DCs were administered intravenously at a dose of $5 \cdot 10^{5}$ cells/mouse [10] in $0.2 \mathrm{ml}$ complete medium on the $7^{\text {th }}(n=5), 14^{\text {th }}(n=5)$ or $21^{\text {st }}(n=5)$ days of AA development. In each group, 7 days after the injection of DCs, on $14^{\text {th }}, 21^{\text {st }}$ and $28^{\text {th }}$ days respectively, we determined the content of Treg in the spleen and $\mathrm{Al}$ of all experimental group animals. Five experiments were performed; each group consisted of five animals. Controls animals $(n=5)$ were injected with bone marrow mononuclear cells at the same concentration as tolDCs $\left(5 \cdot 10^{5}\right.$ cells/mouse). The comparison group was animals $(n=5)$ administered intravenously with dexamethasone - Dex (KRKA, Slovenia) $0.022 \mathrm{mg} / \mathrm{mouse}$ in $0.2 \mathrm{ml}$ saline [16].

Flow cytometric analysis of the cells. Monoclonal anti-mouse antibodies CD14-FITC, CD11b-FITC, CD83-FITC, CD80-FITC, CD86 and CD86FITC (BD Biosciences, USA) were used to identification ex vivo grown tolerogenic DCs on a FACS Calibur flow cytometer (Becton Dickinson, USA) according to the manufacturer's instructions. The Treg content in the spleen of animals at various stages of AA development and after the introduction of tolDCs was evaluated using monoclonal anti-mouse antibodies CD4-FITC, CD25-PE, FOXP3-PE (BD Biosciences, USA) according to the manufacturer's instructions. Isotype-Ig antibodies (BD Biosciences, USA) were used as a negative control. Statistical analysis of the data obtained by flow cytometry was performed using WinMDi 2.8 software (Joseph Trotter, Scripps Institute, USA).

Statistical data processing was performed using the SPSS Statistics 17.0 software (IBM, USA). The obtained experimental data are presented as the mean \pm standard deviation. The reliability of differences between the groups was evaluated by Mann-Whitney $U$ test. The differences were considered statistically significant at $p<0.05$.

\section{RESULTS AND DISCUSSION}

The most manifesting sign of the initiation of the AA in rodents is the edema of the affected joint, which was determined in mice of the experimental group (Fig. 1)

According to literature $[17,18,19]$, the edema of the joints in the term from 4 to 9 days after the induction of $A A$ is a consequence of intraarticular changes of the synovium, followed by the formation of granulation tissue, which is characterized as an acute stage of the pathology. Al had the maximum value in animals on the $14^{\text {th }}$ day of $A A$ development $(1,802 \pm 0,058)$ (Fig. 2 A). The period from 10 to 20 days of AA development corresponds to the most intensive growth of connective tissue, which can cause more pronounced edema of the joints and is characterized as a phase of clinical manifestation of the disease. The following is a chronicity of the inflammation while maintaining a high level of $\mathrm{Al}$ throughout the observation period (up to 28 days).

$\mathrm{RA}$ is accompanied by the destruction of connective tissue, which main component is glycoproteins. Their level is determined by the content of sialic acids and seromucoids. In this regard, the determination of sialic acids and seromucoids as the markers of the inflammation in assessing the severity of the disease, monitoring its course and control of the treatment effectiveness is expedient $[20,21]$.

Thus, after AA induction, the animals had an increase in the level of seromucoids and sialic acids in the serum, which indicators reached a peak by the $14^{\text {th }}$ day of disease development, which is consistent with the maximum arthritis index (Fig. 2 A, B, C). During the chronicity of the in-
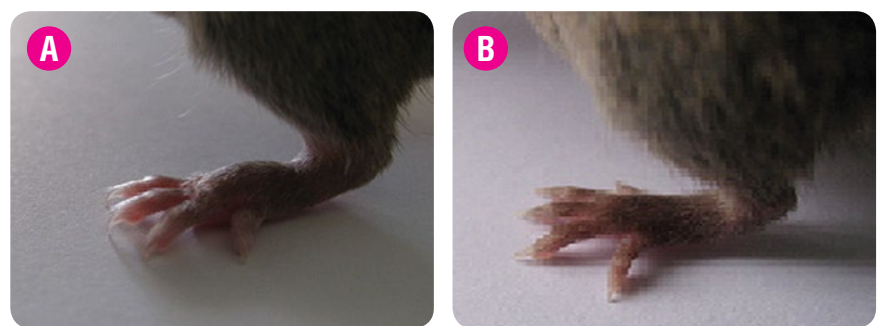

Fig. 1. The image of local inflammation in the form of edema of the distal metatarsus of mouse hind paw with adjuvant arthritis model (A) compared to control mice (B) 


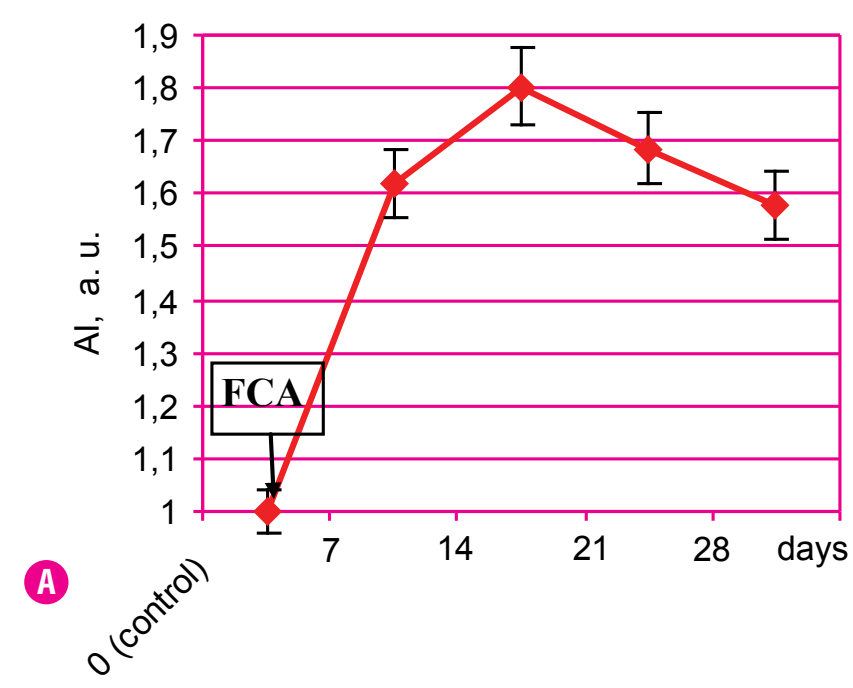

flammation, these index decreased, but until the $28^{\text {th }}$ day remained above the control values.

One of the reasons for the tolerance disorder at RA may be a decrease in Treg content or their functional defects. Most researchers observed a decrease in the relative number of circulating Tregs [22, 23, 24], in some studies, there was its increase [25] or the absence of differences compared to healthy patients [26]. Our studies showed a decrease of Treg content in different periods of AA clinical course (Fig. 3).

In experimental murine models, it has been shown that Treg deficiency, namely $\mathrm{CD} 4^{+} \mathrm{CD} 25^{+}$cells, although it is not a major factor in the arthritis pathogenesis, plays an important role in supporting the autoimmune process [27]. Reduced Treg activity in autoimmune diseases may be due to inadequate expression of cell surface molecules involved in the mechanism of contact-dependent suppression, such as CTLA-4, CD39, CD223, FAS ligand (CD95), granzyme $A$, as well as the loss of ability to secrete soluble factors TGF, IL-10, IL-35. The impact on immunosuppression mechanisms is primarily due to genetic factors. The location of immune cells, the involvement of antigen-presenting cells and cytokines (such as TNF-a), which can affect Treg function, are also of a great importance [5]. More commonly, the expression of the most specific marker, the Foxp3 transcription factor, which provides differentiation and suppressor function of $\mathrm{FOXP3}^{+}$Treg, is associated with the Treg-cell population.

Given this, it was advisable to determine the content of FOXP3 $3^{+}$cells in the spleen cells of animals with $\mathrm{AA}$, along with the number of $\mathrm{CD} 4^{+} \mathrm{CD} 25^{+}$ cells in the presence of intracellular protein scurfin, which determines their suppressor function. It is known that FOXP3+ Treg along with $\mathrm{CD} 4^{+} \mathrm{CD} 25^{+}$ can be reckon to other cells with regulatory activity, such as Th3 and $\mathrm{Tr} 1$ producing anti-inflammatory mediators TGF- $\beta$ and IL-10 [28].

Thus, we found that the relative number of $\mathrm{CD} 4^{+} \mathrm{CD} 25^{+}$and $\mathrm{FOXP} 3^{+}$ cells had no significant differences in intact mice of the control group. On the $7^{\text {th }}$ day of AA development, the content of CD4+CD25+ i FOXP3 ${ }^{+}$ cells decreased by 1.6 and 1.4 times, respectively, of the control (Fig. 3), which may contribute to the breakdown of tolerance in the development of the arthritis. This is consistent with the data of Fontenot J. et al., who discovered a special genetic mechanism of dominant tolerance mediated by the FOXP3 protein that protects the body against autoimmune diseases and chronic infections [29]. In our study, the increase of Al was the most important at immune disorders.

On the $14^{\text {th }}$ day, the number of $\mathrm{CD} 4^{+} \mathrm{CD} 25^{+}$cells increased slightly compared to the $7^{\text {th }}$ day (remaining below the control value by $25 \%$ ), while the content of $\mathrm{FOXP3}^{+}$cells increased by 1.6 times. This may indicate the presence of FOXP3 protein in other cells with regulatory activity. It is known that overexpression of the FOXP3 protein may cause dysfunction of Treg and $\mathrm{CD} 4^{+} \mathrm{CD} 25^{+}$cells, which leads to a decrease in their proliferation and production of anti-inflammatory cytokines and in some cases to the development of severe immunodeficiency [28].
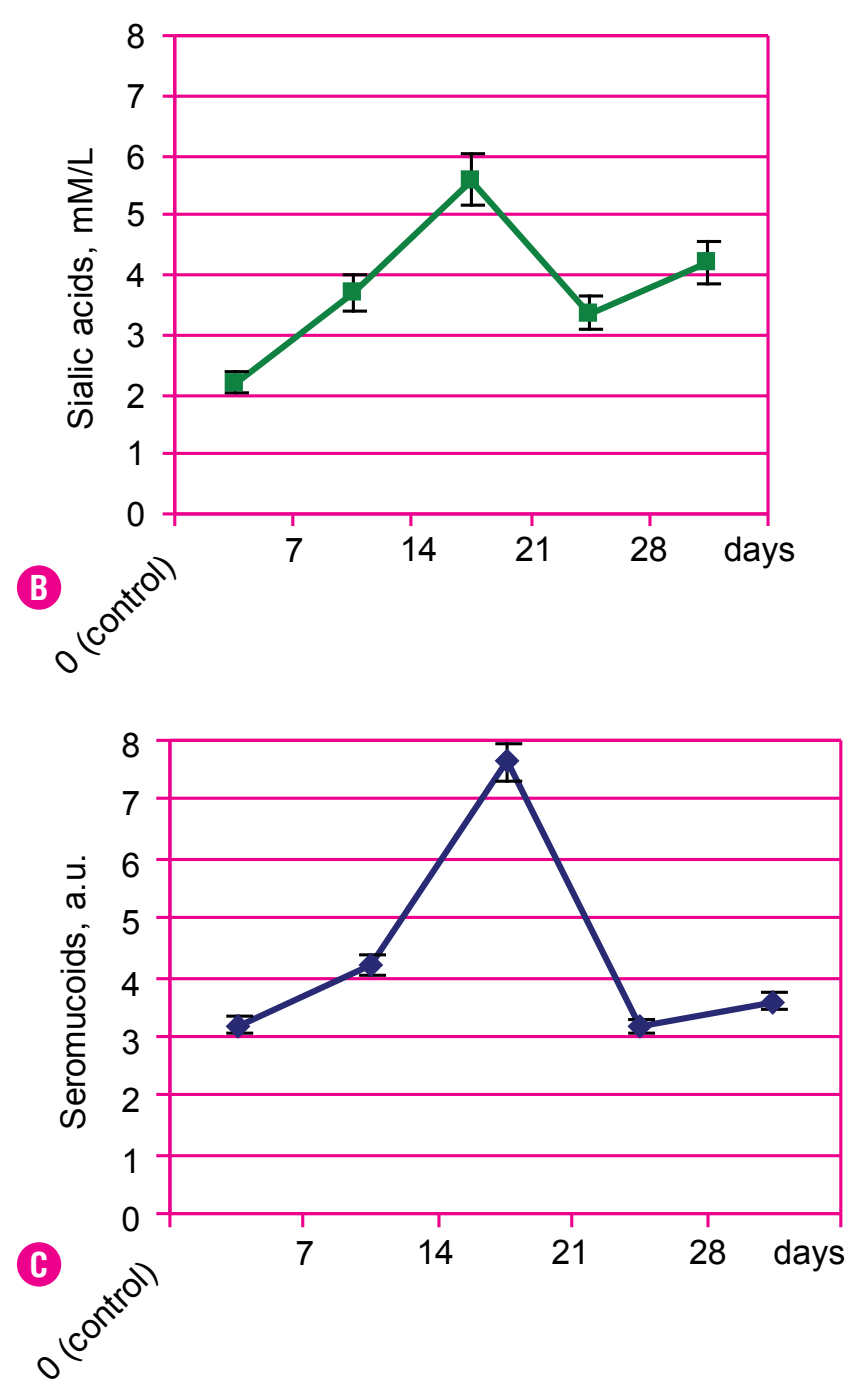

Fig. 2. Dynamics of clinical indicators change at adjuvant arthritis: $\mathbf{A}$ - arthritis index (Al), B - level of sialic acids and $\mathbf{C}$ - level of seromucoids in the serum of blood; $\mathrm{n}=5$.

Note: FCA - Freund's Complete Adjuvant.

On the $21^{\text {st }}$ day of the arthritis development, on the contrary, there was an active proliferation of CD4+CD25+ cells at a low level of FOXP3 ${ }^{+}$ cells in the general population of spleen cells, which testifies to their reduced functional activity. This expansion of Treg in the spleens of animals with AA during this period was noted by other authors [28, 30], which may be the result of increased expression of CD25 in response to an increase in proinflammatory cytokines IL2, prostaglandin E2, IFN $\gamma$, which are mediators of inflammation. There is every reason to suppose that at the stage of active proliferation of $\mathrm{CD} 4{ }^{+} \mathrm{CD} 25^{+}$cells, their suppressor activity is reduced, as evidenced by the low content of FOXP3 protein and high rate of arthritis index up to $1.686 \pm 0.073$ a.u. (Fig. 3).

On the $28^{\text {th }}$ day of $\mathrm{AA}$, the content of both $\mathrm{CD} 4^{+} \mathrm{CD} 25^{+}$and FOXP3 ${ }^{+}$ cells decreased compared to the $21^{\text {st }}$ day of the arthritis development. In this period, the functional activity of $\mathrm{CD} 4^{+} \mathrm{CD} 25^{+}$cells was reduced, resulting in high arthritis index (1.578 \pm 0.099 a.u.). Thus, at all stages of AA, there was a marked dysfunction of the Treg immunity and violation of clinical and diagnostic parameters of animals that need correction of immune system.

Given the ability of tolDCs to induce naïve T-cells into Treg which secret suppressive tolerogenic factors such as IL-10, TGF- $\beta$, retinoic acid and programmed death ligands [5], we investigated the possibility of using immature syngeneic DCs to induce Treg in the recipients with AA. 


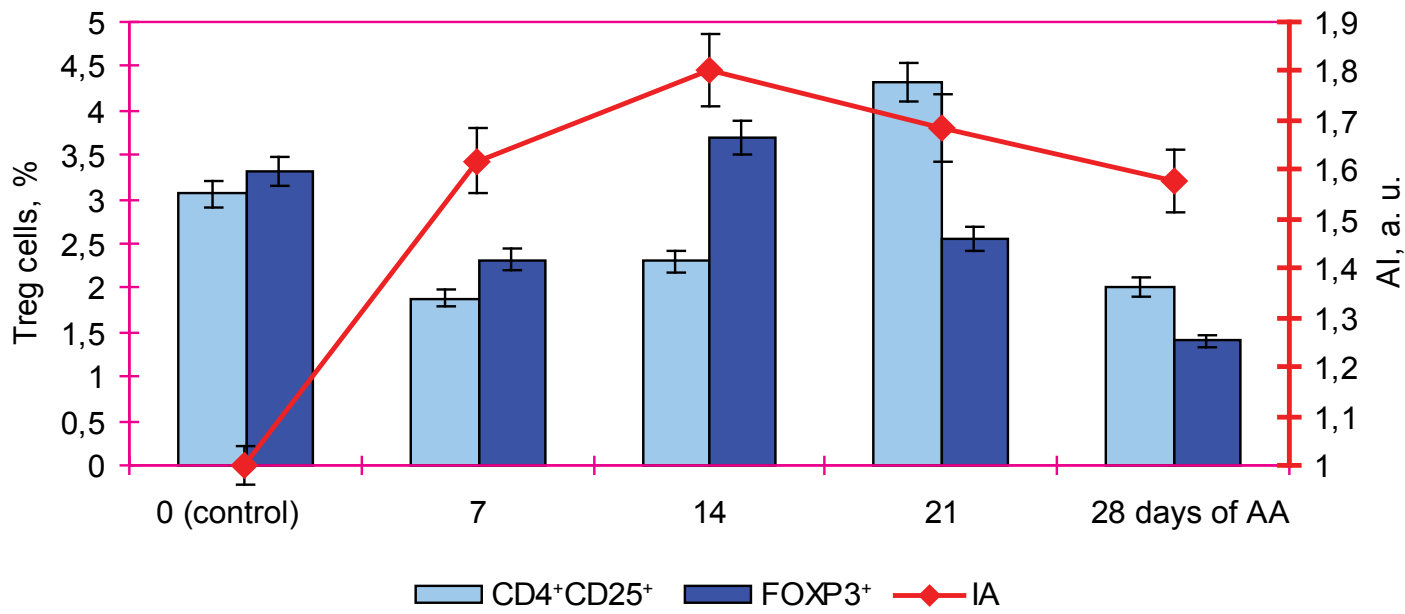

Fig. 3. The content of

Treg in the spleen of animals and arthritis index in the dynamics of adjuvant arthritis development.

To this purpose, we have obtained DCs in vitro and confirmed they appropriate tolerogenic phenotype.

The analysis of the literature allowed us to select a number of monoclonal antibodies: CD14, CD83, CD11b, CD80, CD86, which are negative or positive markers that characterize the obtained DCs as tolerogenic (Table 1) $[12,13,14]$.

Monocyte differentiation into immature DCs was accompanied by the loss of CD14 antigen, low expression of CD83 marker and co-stimulatory molecules CD80/86, as well as high level of CD11b. The resulting immature tolDCs had CD14-CD11 b+ CD83 ${ }^{\text {low }} C D 80 / 86^{\text {low }}$ phenotype. On the $7^{\text {th }}$ day of cultivation, their relative content was $90 \%$ of the seeded cells at the start of cultivation.

Since the resistance to in vivo maturation in autoimmune diseases is probably the most important feature among all other characteristic features of tolDCs [31, 32, 33], the next stage of the study was the approbation of tolDCs obtained in culture on the AA model.

The analysis of the Treg immunity in animals after tolDCs adoptive treatment depending on the AA stage $(7,14$ and 21 days) is presented in Fig. 4. With the introduction of tolDCs into the animals on the $7^{\text {th }}$ day of $A A$ development (AA-7) (Fig. 4 A), there was an 1.6-fold increase of $\mathrm{CD} 4{ }^{+} \mathrm{CD} 25^{+}$cells content and a 1.5 -fold decrease in FOXP3+ cells compared to untreated animals (AA-14). This may indicate the ability of tolDCs to stimulate $\mathrm{CD} 4^{+} \mathrm{CD} 25^{+}$cell proliferation during this time with reduced production of FOXP3 protein in Treg, which is responsible for their suppressor function. In their turn, Dex and MNCs used as comparison groups contributed less to the normalization of these indicators. In addition, according to the arthritis index, the transfer of tolDCs at this time was not effective, since the Al after a week (14 days of effect evaluation) did not differ from that in untreated animals. Our data is consistent with that of van Duivenvoorde et al., who also did not obtain a positive effect with the introduction of tolDCs during the acute stage of arthritis [34]. It should be noted that the injection of Dex or MNCs to animals with AA-7 also did not cause a decrease in $\mathrm{Al}(1.736 \pm 0.165$ and $1.730 \pm 0.093$ a.u., respectively).
The introduction of tolDCs on the $14^{\text {th }}$ day of arthritis model (AA14) within a week caused significant changes of $C D 4^{+} C D 25^{+}$and FOXP3 ${ }^{+}$ cells content, which were not significantly different from the intact control group (Fig. 4 B). This may indicate a stimulation of Treg function after the introduction of tolDCs at this time. Moreover, only in this group, compared to other groups, the Al decreased significantly, as close as possible to the control group ( $1.154 \pm 0.109$ and $1.0 \pm 0.01$ a. u., respectively).

The introduction of tolDCs on the $21^{\text {st }}$ day of arthritis (AA-21) largely than Dex and MNCs corrected the arthritis index and both Treg subpopulations. At the same time, the reduction of the joint edema was less than with the transfer of tolDCs on the $14^{\text {th }}$ day (Fig. 4 C).

The use of tolDCs during the clinical manifestation of the arthtitis (14 $21^{\text {st }}$ days) showed greater corrective activity of the Treg immunity, leading to a decrease in arthritis index, compared to Dex and MNCs groups.

When using Dex, we also observed an increase in the content of FOXP $3^{+}$cells, but they exhibited less suppressor activity than induced by tolDCs, according to the arthritis index. Moreover, as noted by Prado $\mathrm{C}$. et al. [35], dexamethasone ability to potentiate FOXP3 protein expression in Treg in vitro did not correlate with their regulatory activity. However, in our studies, the positive dynamics of the animal's clinical status, namely arthritis index, were noted with the injection of Dex on the $14^{\text {th }}$ and $21^{\text {st }}$ days of AA. The fact is that the mechanism of Dex impact has certain features. First, corticosteroids are powerful immunosuppressive agents [36]. The transcription factor GILZ is crucially important in immunosuppression. It is activated by glucocorticoids, causing the inhibition of nuclear factor kappa-B (NFkB), which in its turn contributes to the reduction of proinflammatory cytokines production [37]. In addition, epigenetic regulation of genes, primarily DNA methylation, plays an essential role in controlling their function and is involved in the expression of Treg transcriptional regulator FoxP3 [38]. The mechanism underlying this unique epigenetic effect of glucocorticoids is associated with a decrease in DNA methyltransferase gene expression, which leads to a significant inhibition of DNA methylation [39]. This causes impaired gene transcriptional activity and, consequently, can lead to an increase in FoxP3 production.

Table 1. Phenotypic markers of tolerogenic DCs.

\begin{tabular}{|c|c|}
\hline CD14 & glycoprotein receptor expressed on monocytes, macrophages, Kupffer cells, leukocytes \\
\hline CD83 & $\begin{array}{l}\text { immunoglobulin superfamily molecule, the most characteristic marker of fully differentiated dendritic cells; absent or poorly } \\
\text { expressed on tolerogenic DCs }\end{array}$ \\
\hline CD80/86 & $\begin{array}{l}\text { membrane proteins of immunoglobulins superfamily expressed on antigen-presenting cells, as well as mature DCs and serve } \\
\text { as a co-stimulatory signal for T-lymphocytes activation and survival }\end{array}$ \\
\hline CD11B & integrin Mac-1, a molecule expressed on immature tolerogenic and absent on mature immunogenic DCs \\
\hline
\end{tabular}



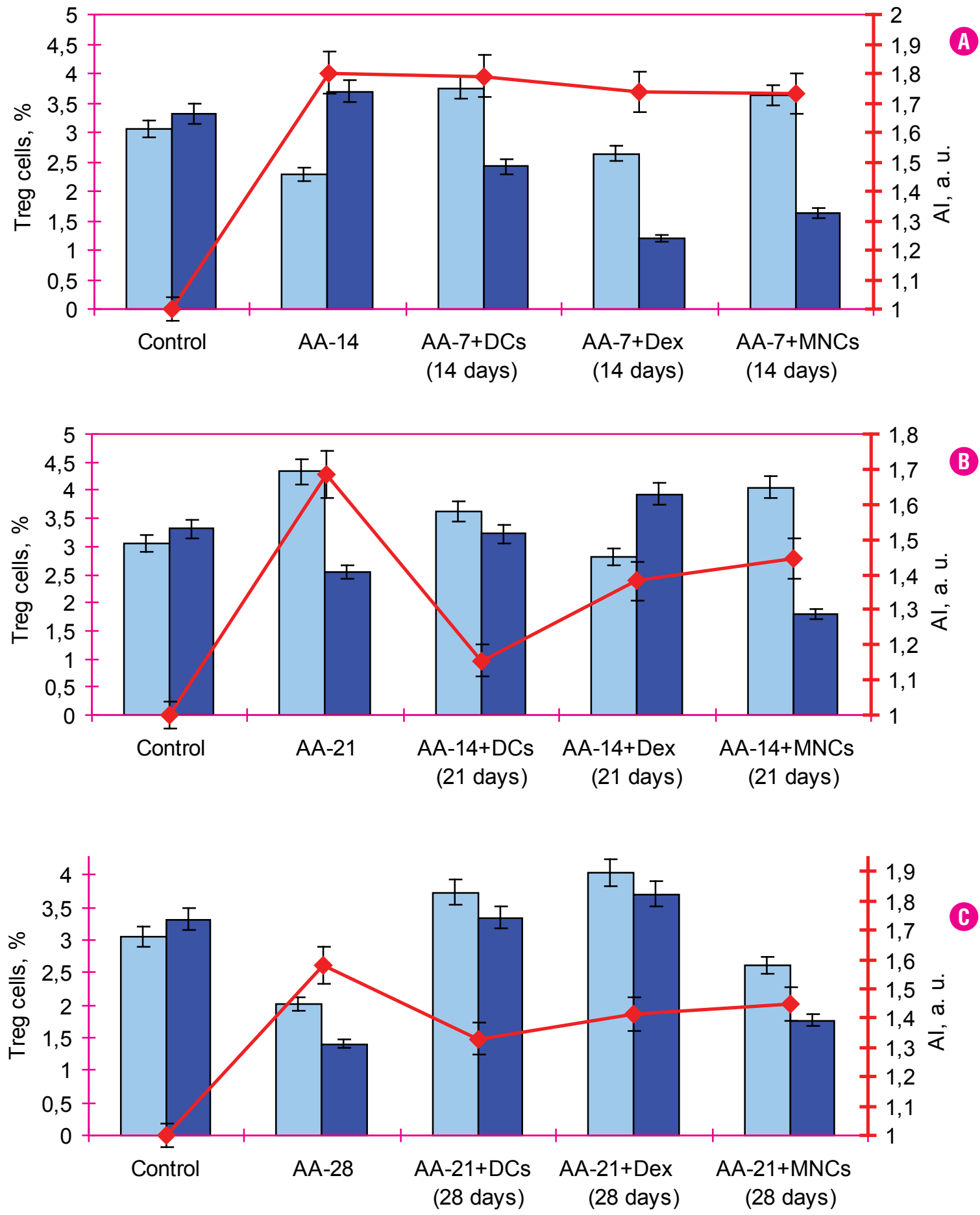

After the transfer of MNCs on the $14^{\text {th }}$ and $21^{\text {st }}$ days of arthritis, Al also decreases, but to a lesser extent comparing to Dex and even less tolDCs groups. MNCs are known to contain mesenchymal stem cells that produce anti-inflammatory mediators. Due to the secretion of IDO, TGF- $\beta$, they are able to induce Treg, and due to the secretion of PGE2 to inhibit DCs maturation [40]. It is this fact that was noted in our study. The injection of MNCs stimulated the proliferation of CD4 ${ }^{+} \mathrm{CD} 25^{+}$cells, but did not affect the content of FOXP3 $3^{+}$Treg cells, which is characteristic of tolDCs. Therefore, the induction of $\mathrm{FOXP3}^{+}$Treg is one of the main mechanisms by which DCs maintain immune tolerance $[11,28]$.
A Fig. 4. The content of Treg cells and arthritis index before and after the injection of tolDCs, Dex, BM-MNCs to animals with adjuvant arthritis (AA). Injections: $\mathbf{A}-$ on the $7^{\text {th }}$ day of $A A$, assessment on the $14^{\text {th }}$ day; B - on the $14^{\text {th }}$ day, assessment on the $21^{\text {st }}$ day; $\mathbf{C}$ - on the $21^{\text {st }}$ day, assessment on the $28^{\text {th }}$ day; $\mathrm{n}=5$. 


\section{CONCLUSION}

Summarizing the above data, we can conclude about the role of terms of cells injection in the manifestation of their therapeutic effect. The greatest therapeutic efficacy was shown by tolDCs introduced on the 14th day of the arthritis. It was during this period that they adjusted the Treg content in recipients, which promoted to normalize their clinical status.

Obviously, tolDCs implement their immune-correcting effect much earlier than glucocorticoids, which is characterized by a later than at the injection of tolDCs manifestation of the corrective effect of dexamethasone.

The study was carried out within the programme «Molecular-genetic and biochemical mechanisms of regulation of cellular and systemic interactions in physiological and pathological states» on the topic «The study of the molecular mechanisms of tolerogenic activity of cryopreserved dendritic cells at their adoptive use».

\section{REFERENCES}

1. Chae WJ, Bothwell ALM. Therapeutic Potential of Gene Modified Regulatory T Cells: From Bench to Bedside. Front Immunol. 2018; 9:303. D0I: 10.3389/ fimmu.2018.00303. eCollection 2018.

2. Dastrange $M$, Oukka $M$, Bettelli $E$. Foxp3 interacts with nuclear factor of activated T cells and NF-B to repress cytokine gene expression and effector functions of $T$ helper cells. PNAS. 2005; 102(14):5138-5143.

3. Han GM, O'Neil-Andersen NJ, Zurier RB, et al. CD4CD25 high T cell numbers are enriched in the peripheral blood of patients with rheumatoid arthritis. Cell Immunol. 2018; 253:92-101.

4. Endharti AT, Okuno Y, Shi Z, et al. CD8+CD122+ regulatory T cells (Tregs) and CD4+ Tregs cooperatively prevent and cure CD4+ cell-induced colitis. J Immunol. 2011; 186(1):41-52.

5. Bykovskaya SN, Karasev AV, Lokhonina AV, et al. Analiz T-regulyatornykh kletok CD4+CD25+FOXP3+ pri autoimmunnykh zabolevaniyakh [Analysis of T-regulatory cells $\mathrm{CD4}^{+} \mathrm{CD} 2{ }^{+} \mathrm{FOXP3}+{ }^{+}$in autoimmune diseases]. Molekulyarnaya meditsina - Molecular medicine. 2013; 3:20-28. [In Russian]

6. Malysheva IE, Topchieva LV, Kurbatova IV. Ekspressiya gena FOXP3 i profil' tsitokinov u bol'nykh revmatoidnym artritom pri lechenii metotreksatom [F0XP3 gene expression and cytokine profile in patients with rheumatoid arthritis in the treatment of methotrexate]. Immunopatologiya, allergologiya, infektologiya Immunopathology, allergology, infectology. 2015; 2:6-10. [In Russian]

7. Nasonov EL. Farmakoterapiya revmatoidnogo artrita: rossiyskie i mezhdunarodnye rekomendatsii [Pharmacotherapy of rheumatoid arthritis: Russian and international recommendations]. Klinicheskaya farmakologiya i terapiya - Clinical Pharmacology and Therapy. 2016; 1(25):67-76. [In Russian]

8. Corsiero E, Marrelli A. An update on research advances in rheumatoid arthritis: from clinic to basic science. J Lab Precis Med. 2018; 54(3):1-9

9. Hilkens CMU, Isaacs JD, Thomson AW. Development of dendritic cell-based immunotherapy for autoimmunity. Int Rev Immunol. 2010; 29:156-183.

10. Yang J, Yang $Y$, Ren $Y$, et al. A Mouse model of adoptive immunotherapeutic targeting of autoimmune arthritis using allo-tolerogenic dendritic cells. PLoS ONE. 2013; 8(10):77729.

11. Sennikov SV, Kulikova EV, Knauer NYu, et al. Molekulyarno-kletochnye mekhanizmy, oposreduemye dendritnimi kletkami, uchastvuyushchie v induktsii tolerantnosti [Molecular cell mechanisms mediated by dendritic cells involved in the induction of tolerance]. Meditsinskaya immunologiya - Medical immunology. 2017; 19(4):359374. [In Russian]

12. Goltsev AM, Dubrava TG, Yampolska $K Y$, et al. Optymizacija metodu oderzhannja nezrilyh dendrytnyh klityn dlja terapevtychnogo zastosuvannja [The optimization of method obtaining immature dendritic cells for therapeutic use]. Fiziolohichnyi zhurnal. 2018; 64(5):33-40. [In Ukrainian]

13. Nekhaeva TL. Optimizatsiya tekhnologii i stardatizatsiya polucheniya protivoopukholevykh vaktsin na osnove autologichnykh dendritnykh kletok: dis. ...kand. med. nauk [Optimization of technology and standardization of obtaining antitumor vaccines based on autologous dendritic cells]. Federal State Budgetary Institution «National Medical Research Center of Oncology named after N.N. Petrov» of the Ministry of Health of the Russian Federation. 2014. [In Russian]

14. Tsaturov ME, Talaev VYu, Matveichev AV, et al. Tolerogennye dendritnye kletki - sozrevanie i funktsii v eksperimentakh in vitro [Tolerogenic Dendritic Cells - Maturation and Functions in in vitro experiments]. Meditsinskiy al'manakh - Medical Almanac. 2010; 2(11):263-266. [In Russian]

15. Kamyshnikov S. Spravochnik po kliniko-biokhimicheskoy laboratornoy diagnostike [Handbook of clinical and biochemical laboratory diagnostics]. 2000; 2:64-66. [In Russian]

16. Oxenkrug GF, McIntyre IM, Stanley M, et al. Dexamethasone suppression test: experimental model in rats, and effect of age. Biol Psychiatry. 1984; 19:413-416.

17. Saratikov AS, Vengerovsky Al, Prishchept TP. Ad»yuvantnaya bolezn' (morfologiya, patogenez, eksperimental'naya terapiya) [Adjuvant disease (morphology, pathogenesis, experimental therapy)]. Tomsk, 1983. 101 p. [In Russian]

18. Donaldson LF, SeckI JR, McQuenn DS. A discrete adjuvant-induced monoarthritis in the rat: effects of adjuvant dose. J Neurosci Methods. 1993; 49:5-10.

19. Chillingworth NL, Donaldson LF. Characterization of Freund's complete adjuvant-induced model of chronic arthritis in mice. J Neurosci Methods. 2003; 128:45-52.

20. Yampolskaya EE, Kravchenko MA, Dubrava TG, et al. Regulyatsiya immunovospalitel'nogo protsessa u zhivotnykh s ad»yuvantnym artritom kriokonservirovannymi kletkami fetal'noy pecheni [Regulation of the immune-inflammatory process in animals with adjuvant arthritis by cryopreserved cells of the fetal liver]. Vestnik KhNU - Bulletin KhNU. 2012; 15(1008):177-186. [In Russian]

21. Cui Z, Liu R, Wang A, et al. Correlation between sialic acid levels in the synovial fluid and radiographic severity of knee osteoarthritis. Exp Ther Med. 2014; 8:255-259.

22. Sakaguchi S. Regulatory T cells: history and perspective. Methods Mol Biol. 2011; 707:3-17.

23. Faye AH Cooles, John D, Anderson AE. Treg Cells in Rheumatoid Arthritis: An Update Curr Rheumatol Rep. 2013; 15(352):2-9.

24. Papagoras C, Markatseli TE, Petsiou A, et al. Co-stimulation modulation improves Rheumatoid Arthritis despite reducing the proportion of CD4 ${ }^{+}$CD25 high $T$ regulatory cells. Mediterr J Rheumatol. 2016; 27(1):15-19.

25. Monte K, Wilson C, Fei Shih F. Increased Number and Function of FoxP3 Regulatory T Cells During Experimental Arthritis. Arthritis Rheum. 2008; 58(12):3730-3741.

26. Liu MF, Wang CR, Fung $L L$, et al. The presence of cytokine-suppressive $C D 4^{+} C D 25^{+} T$ cells in the peripheral blood and synovial fluid of patients with rheumatoid arthritis. Scand J Immunol. 2005; 62:312-317. 
27. McGeachy MJ, Stephens LA, Anderton SM. Natural recovery and protection from autoimmune encephalomyelitis: Contribution of CD4+CD25+ regulatory cells within the central nervous system. J Immunol. 2005; 175(5):3025-3032

28. Yarilin $A A$, Donetskova $A D$. Estestvennye regulyatornye T-kletki i faktor FOXP3 [Natural regulatory T cells and FOXP3 factor]. Immunologiya - Immunology. 2006; 3:176-188. [In Russian]

29. Fontenot $J$, Rudensky A. A well adapted regulatory contrivance: regulatory T cell development and the forkhead family transcription factor Foxp3. Nature Immunol. 2005; 6:331-337.

30. Lutsenko ED. Monitoring sostoyaniya pula T-regulyatornykh kletok pri ad'yuvantnom artrite posle primeneniya kriokonservirovannykh kletok platsenty [The monitoring of the state of the pool of T-regulatory cells in adjuvant arthritis after the cryopreserved placental cells use]. Liki - Iyudini. Suchasni problemi stvorennya, vivchennya i aprobatsiï likars'kikh zasobiv: Materiali XXVII naukovopraktichnoï konferentsiï z mizhnarodnoyu uchastyu. Kharkiv, National University of Pharmacy. 2010:325-333. [In Russian]

31. Adler HS, Steinbrink K. Tolerogenic dendritic cells in health and disease: friend and foe! Eur J Dermatol. 2007; 17:476-491.

32. Morelli AE, Thomson AW. Tolerogenic dendritic cells and the quest for transplant tolerance Nat Rev Immunol. 2007; 7:610-621.

33. Suwandi JS, Nikolic T, Roep BO. Translating mechanism of regulatory action of tolerogenic dendritic cells to monitoring endpoints in clinical trials. Front Immunol. 2017; 8:1598.

34. van Duivenvoorde LM, Han WG, Bakker AM, et al. Immunomodulatory dendritic cells inhibit Th1 responses and arthritis via different mechanisms. J Immunol. 2007; 179(3):1506-1516.

35. Prado C, Gómez J, López P, et al. Dexamethasone upregulates FOXP3 expression without increasing regulatory activity. Immunobiology. 2011 ; 216:386-392.

36. Giles AJ, Hutchinson MND, Sonnemann HM, et al. Dexamethasone-induced immunosuppression: mechanisms and implications for immunotherapy. J Immunother Cancer. 2018; 6(1):51.

37. Hoppstädter J, Hachenthal N, Valbuena-Perez JV, et al. Induction of Glucocorticoid-induced Leucine Zipper (GILZ) Contributes to Anti-inflammatory Effects of the Natural Product Curcumin in Macrophages. J Biol Chem. 2016; 291(44):22949-22960.

38. Kennedy A, Schmiudt EM, Cribbs AP, et al. A novel upstream enhancer of FOXP3, sensitive to methylation-induced silencing, exhibit dysregulatrd methylation in rheumatoid arthritis T reg cells. Eur J Immunol. 2014; 44:2668-2678.

39. Cribbs $A P$, Kennedy $A$, Penn $\mathrm{H}$, et al. Methotrexate restores regulatory $\mathrm{T}$ cell function through demethelation of the FoxP3 upstream enhancer in patients with rheumatoid arthritis Arthritis Rheum. 2015; 67:1182-1192.

40. Figueroa FE, Carrión F, Villanueva S, et al. Mesenchymal Stem Cell treatment for autoimmune diseases: a critical review. Biol Res. 2012; 45:269-277.

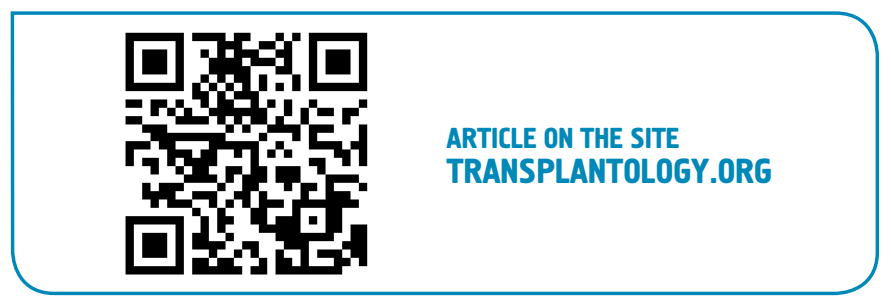

The authors declared no potential conflicts of interest with respect to the research, authorship, and/or publication of this article.

Received: June 26, 2019

Accepted: September 30, 2019 